\title{
Postscript: Feminist Legal Theory in the 21st Century
}

\author{
Margaret Thornton $(1 D$ \\ ANU College of Law, The Australian National University, Canberra, ACT 2600, Australia; \\ Margaret.thornton@anu.edu.au
}

Received: 16 July 2020; Accepted: 20 July 2020; Published: 21 July 2020

\begin{abstract}
This editorial takes the form of a short postscript to a special issue of Laws published in 2019-20. It shows how feminist legal theory (FLT), a corollary of second wave feminism, was initially embraced by law schools but soon subjected to a backlash. FLT was nevertheless able to turn around the negative discourse of post-feminism to show that the "post" can mean not just the end but a new beginning. The Special Issue attests to the resurgence of FLT in the 21st century.
\end{abstract}

Keywords: feminist legal theory; backlash; post-feminism; 21st century

As is the case with many political movements, the fortunes of feminism have ebbed and flowed. Feminist legal theory (FLT) emerged as a corollary of second wave feminism and the critiques of knowledge that were central to it. Feminist scholars were able to show that the claimed universals, or what Catharine MacKinnon (1989, p. 162) referred to as "point of viewlessness", were in fact partial and invariably represented a masculinist point of view. The humanities and the social sciences led the way in critiquing universality (e.g., Okin 1980; Smith 1988; Code 1991). The fundamental question was: how can claims to universality be valued if the voices of 50 per cent of the population are missing? Of course, this figure is likely to be much greater when we take into account the absence of the voices of Indigenous peoples and other marginalised groups. The critique of universalism struck a particular chord with feminist legal scholars as legal positivism, the favoured mode of adjudication in the common law world, averred that law was neutral, objective and true and could be relied upon to produce "right answers".

As well as exposing the masculinity of the paradigmatic legal person- "the man of law" (Naffine 1990)—feminist legal theory sought to shift the critical gaze from the public to the private sphere in accordance with the central trope of the feminist movement: "the personal is the political". Thus, attitudes towards issues of sexual assault, violence and bodily autonomy began to change and the criminalisation of harms against women began to be taken more seriously. FLT had a particular interest in the affective side of life, as opposed to the conventional doctrinal and applied focus on property and profits that typified the law curriculum in most law schools and were deemed necessary for admission to legal practice. What was significant about the methodology of FLT was the nature of the questions asked and the giving of voice to those conventionally discounted by law, such as the survivors of sexual assault and domestic violence.

FLT did not restrict its focus to issues conventionally regarded as "women's issues" as it also developed critiques of fields of law from which a feminist presence had been either excluded or marginalised, such as international law (e.g., Charlesworth et al. 1991). The scholarly endeavours of feminist legal scholars resulted in FLT being included in the curricula of many law schools and received the endorsement of academic gatekeepers. This even led to the Australian government funding gender-sensitive materials for inclusion in the compulsory core of the law curriculum (Thornton 2019, p. 15).

The apparent embrace of FLT was nevertheless short-lived, with the very success of feminism resulting in a backlash against it and the category "woman" being attacked as essentialist (e.g., Behrendt 1993). Popular culture began to deride feminism as a movement that was passé and belonged to a 
previous generation. The hostile environment led to the emergence of the discourse of "post-feminism", which some feminists saw as a ploy designed to depoliticise feminism. As Chandra Mohanty notes (Mohanty 2013, p. 972), through depoliticization, "the state is made postfeminist before feminists achieve gender justice".

The reaction against feminism coincided with the neoliberal turn, which resulted in disinvestment by the state in higher education, a problem that was exacerbated by the global financial crisis of 2008-2009. The cost of tuition was passed onto students, which encouraged them to be utility maximisers - that is, to focus on applied subjects that they believed would make them more attractive in the job market (Thornton 2012). They began to say that they no longer wanted FLT on their testamurs, in the belief that it could harm their chances of employability. Austerity measures by law schools also encouraged a more applied focus in the curriculum, creating a parlous environment for the future of FLT.

However, the "post" in "post-feminism" is ambiguous: it can suggest that feminism's days are numbered, but it can also signal a new beginning as a result of an epistemological break (Lewis 2014, p. 1849). As FLT did not fade away, I suggest that the latter meaning is more appropriate.

It was sexual harassment that gave feminism an adrenalin shot in the arm in accordance with the positive understanding of the "post". The catalyst was the revelation that Hollywood movie mogul, Harvey Weinstein, had sexually harassed multiple women, including prominent movie stars (Entertainment News 2020). However, it was not as though sexual harassment had ever gone away as it has always been a corollary of the lives of working women, as Catharine MacKinnon (1979) compellingly showed more than 40 years ago. The international publicity that Weinstein attracted encouraged other women to speak up. This resulted in the exposure of predatory behaviour by prominent men elsewhere and \#MeToo became a global movement. The impact of the \#MeToo movement on the resurgence of feminism and FLT was extraordinary.

One striking response was that of the International Bar Association (IBA), which commissioned a survey of 7000 legal professionals in 135 countries and produced a landmark report, Us Too? (Pender 2019). The IBA has continued to play a leadership role in respect to sexual harassment in law firms globally, with the development of proactive tools, conferences and webinars. More recently, six women associates lodged a formal complaint against former High Court judge, Dyson Heydon, which was upheld (McClymont and Maley 2020). The Chief Justice of the Australian High Court, Susan Kiefel, went further than the typical male organisational head in that she not only apologised to the women but issued a public statement stressing her "shame" that the harassment had occurred at the High Court (McClymont and Maley 2020).

More generally, interest in feminist legal theory on the part of young women has revived, with the demand for autonomy over their bodies, demands for equal pay and freedom from violence, particularly as women are killed very week by their partners. The neoliberal turn, in conjunction with the wave of moral conservatism that has engulfed many parts of the world, has inspired young women to take a stance as they realise the fragility of the gains of the past.

These changes inspired me to suggest that it was opportune to pursue the theme of Feminist Legal Theory in the 21st Century as a Special Issue of Laws. The call for papers pointed out that, far from being a spent force, FLT was a vital means of making sense of a rapidly changing world. Contributors therefore had considerable scope in which to address a topic of interest. I am pleased to report that the following articles were published in the Special Issue. They encompass an array of topics and represent diverse jurisdictions:

1. Paul Baumgardner, Princeton University, USA: "Ronald Reagan, the Modern Right, and ... the Rise of the Fem-Crits" (Baumgardner 2019). This article explores the foundational role of feminist critical legal scholars, colloquially known as the "Fem-Crits". Baumgardner questions whether the resistance of the Fem-Crits to the conservatism of the 1980s might provide lessons for progressive lawyers and feminist legal theorists in responding to the conservative agenda of the 
Trump administration today. He argues that the successors to the Fem-Crits are indeed able to play an essential role in strengthening progressive movements.

2. Adrian Howe, Independent researcher, Melbourne, Australia: “'Endlessly Valuable' Discursive Work-Intimate Partner Femicide, an English Case Study" (Howe 2019). This article addresses the ongoing issue of violence against women, with particular regard to intimate partner femicide. Howe focuses on the reform of provocation defences in England and Wales. She invokes insights from Carol Smart's 1989 text, Feminism and the Power of Law. Howe argues that Smart's methodology enables legal texts to be read as sites in which the law's truth about gendered relationships can be contested. She illustrates this proposition with reference to recent cases.

3. Karen O'Connell, University of Technology, Sydney, Australia, "Can Law Address Intersectional Sexual Harassment? The Case of Claimants with Personality Disorders" (O'Connell 2019). This article addresses a unique dimension of intersectional discrimination in the context of sexual harassment, namely that of claimants with personality disorders, a notably stigmatised manifestation of disability discrimination. While there are few reported cases, $\mathrm{O}^{\prime}$ Connell argues that, far from strengthening the relevant provision in the Australian federal Sex Discrimination Act, the decisions that she analyses may actually undermine the provision.

4. Kcasey McLoughlin and Alex O'Brien, University of Newcastle, Australia, "Feminist Interventions in Law Reform: Criminalising Image-Based Sexual Abuse in New South Wales" (McLoughlin and O'Brien 2019). While agitation for law reform is a familiar pursuit of feminist legal scholars, image-based sexual abuse is very much a 21st century issue. The article examines the process surrounding the criminalisation of this harm in the state of New South Wales (Australia), paying particular attention to the contradictions associated with "using the master's tools" in law reform. The authors were surprised at the positive reaction to feminist scholarship in this instance as scholars were not only listened to but were also able to set the agenda.

5. Dorota Anna Gozdecka, University of Helsinki, Finland, "Backlash or Widening the Gap?: Women's Reproductive Rights in the Twenty-First Century" (Gozdecka 2020). This article is concerned with the ongoing struggle by women for autonomy over their reproductive rights. With particular regard to Ireland and the United States, Gozdecka argues that the contemporary backlash is a product of the historical fragility around reproductive rights that is enmeshed in issues of religion and political conservatism. She emphasises the elusiveness of lasting reform and doubts the ability ever to be able to claim "victory".

6. Ana Oliveira, University of Coimbra, Portugal, "Subject (in) Trouble: Humans, Robots, and Legal Imagination" (Oliveira 2020). This article sets out to problematise the meaning of the legal subject, which may now transcend that of the human to include the posthuman, anthropomorphised manifestations of nature or robots. In considering some intriguing contemporary examples, Oliveira identifies the biopolitical and epistemological challenges that the new subject presents for law. She argues that the legal subject is "in trouble" but this is always contingent on the cartography of power and knowledge.

Funding: This research received no external funding.

Conflicts of Interest: The author declares no conflict of interest.

\section{References}

Baumgardner, Paul. 2019. Ronald Reagan, the Modern Right, and ... the Rise of the Fem-Crits. Laws 8: 26. [CrossRef]

Behrendt, Larissa. 1993. Aboriginal Women and the White Lies of the Feminist Movement: Implications for Rights Discourse. Australian Feminist Law Journal 1: 27-44. [CrossRef]

Charlesworth, Hilary, Christine Chinkin, and Shelley Wright. 1991. Feminist Approaches to International Law. American Journal of International Law 85: 613-45. [CrossRef] 
Code, Lorraine. 1991. What Can She Know? Feminist Theory and the Construction of Knowledge. Ithaca: Cornell University Press.

Entertainment News. 2020. Timeline: The Harvey Weinstein Story-From Studio to Courtroom in 40 Years. Reuters. February 25. Available online: https://www.reuters.com/article/us-people-harvey-weinstein-timeline/ timeline-the-harvey-weinstein-story-from-studio-to-courtroom-in-40-years-idUSKCN20I1YV (accessed on 20 July 2020).

Gozdecka, Dorota Anna. 2020. Backlash or Widening the Gap?: Women's Reproductive Rights in the Twenty-First Century. Laws 9: 8. [CrossRef]

Howe, Adrian. 2019. “Endlessly Valuable” Discursive Work-Intimate Partner Femicide, an English Case Study. Laws 8: 33. [CrossRef]

Lewis, Patricia. 2014. Postfeminism, Femininities and Organization Studies: Exploring a New Agenda. Organization Studies 35: 1845-66. [CrossRef]

MacKinnon, Catharine A. 1989. Toward a Feminist Theory of the State. Cambridge: Harvard University Press.

MacKinnon, Catharine A. 1979. Sexual Harassment of Working Women: A Case of Sex Discrimination. New Haven: Yale University Press.

McClymont, Kate, and Jacqueline Maley. 2020. High Court Inquiry finds Former Justice Dyson Heydon Sexually Harassed Associates. Sydney Morning Herald. June 22. Available online: https:/www.smh.com.au/national/high-court-inquiry-finds-former-justice-dyson-heydon-sexuallyharassed-associates-20200622-p5550w.html (accessed on 20 July 2020).

McLoughlin, Kcasey, and Alex O’Brien. 2019. Feminist Interventions in Law Reform: Criminalising Image-Based Sexual Abuse in New South Wales. Laws 8: 35. [CrossRef]

Mohanty, Chandra Talpade. 2013. Transnational Feminist Crossings: On Neoliberalism and Radical Critique. Signs: Journal of Women in Culture and Society 38: 967-91. [CrossRef]

Naffine, Ngaire. 1990. Law and the Sexes: Explorations in Feminist Jurisprudence. Sydney: Allen \& Unwin.

O'Connell, Karen. 2019. Can Law Address Intersectional Sexual Harassment? The Case of Claimants with Personality Disorders. Laws 8: 34. [CrossRef]

Okin, Susan Moller. 1980. Women in Western Political Thought. London: Virago.

Oliveira, Ana. 2020. Subject (in) Trouble: Humans, Robots, and Legal Imagination. Laws 9: 10. [CrossRef]

Pender, Kieran. 2019. Us Too? Bullying and Sexual Harassment in the Legal Profession. London: Legal Policy \& Research Unit, International Bar Association.

Smith, Dorothy E. 1988. The Everyday World as Problematic: A Feminist Sociology. Milton Keynes: Open University Press.

Thornton, Margaret. 2012. Privatising the Public University: The Case of Law. Abingdon: Routledge.

Thornton, Margaret. 2019. The Feminist Fandango with the Legal Academy. In Feminism, Postfeminism, and Legal Theory: Beyond the Gendered Subject. Edited by Dorota Gozdecka and Anne Macduff. London: Routledge, pp. 11-29.

(C) 2020 by the author. Licensee MDPI, Basel, Switzerland. This article is an open access article distributed under the terms and conditions of the Creative Commons Attribution (CC BY) license (http://creativecommons.org/licenses/by/4.0/). 